\title{
TECCIENCLA
}

\section{ULTRASOUND APPLICATIONS TO MEDICINE PART I: PHYSICAL PRINCIPLES.}

\author{
Aplicaciones de ultrasonido en medicina. Parte I: Principios Físicos
}

\author{
Fernando Arturo Soler López ${ }^{1}$ \\ ${ }^{I}$ Escuela Colombiana de Carreras Industriales ECCI, Bogotá, Colombia, rectoria@ecci.edu.co
}

Published: 30 July 2013

\begin{abstract}
It describes applications of ultrasound (U.S.) in medicine and its importance from an extensive review of the state of the art, displaying not only relevant in the diagnosis, but a growing interest in the therapeutic treatment, not counting other nonmedical promising developments in sectors such as industry, food, biotech, cosmetic, chemical, nanotechnology, veterinary, etc.., which are not addressed in this paper.

To understand the operation of ultrasonic ultrasound machine and all its components, mainly the transducer, and the versatility of medical uses, it is necessary to systematically address the principles of the U.S. wave properties such as reflection, refraction and absorption, and physical quantities associated with the description of these phenomena, in which have a technological characteristics, namely: reflection factor, refractive index, attenuation, resolving power, density, intensity, frequency and impedance.
\end{abstract}

Keywords: Attenuation, Ultrasound, Frequency, Wave, Piezoelectric, Reflection, Refraction, Resolution, Transducer, Ultrasound.

\section{Resumen}

Este trabajo muestra las distintas aplicaciones del ultrasonido (U.S.) en medicina y su importancia a partir de una concienzuda revisión del estado del arte, visualizando que no sólo es relevante para diagnóstico médico, puesto que se ha observado un creciente interés en el tratamiento terapéutico y en desarrollos no médicos como el industrial, alimentos, biotecnológico, cosmético, procesos químicos, nanotecnología, veterinaria, etc., que no se abordan en el presente trabajo, debido a su extensión; ésta revisión temática está direccionada al campo Médico y su profundidad y extensión han permitido desarrollar dos trabajos: Principios Físicos y Equipos Médicos.

Este artículo de revisión temática facilita al lector la comprensión ulterior de la base científica y funcionamiento de equipos tales como ecógrafos ultrasónicos, entre otros, sus componentes, principalmente el transductor, así como la versatilidad de usos médicos. Es necesario abordar sistemáticamente en esta primera parte los principios de las propiedades ondulatorias del U.S. como la reflexión, la refracción y la absorción, además de las magnitudes físicas asociadas a la descripción de dichos fenómenos, dentro de las cuales se tienen características de orden tecnológico, principalmente: factor de reflexión, índice de refracción, atenuación, poder de resolución, densidad, intensidad, frecuencia e impedancia.

Palabras clave: Atenuación, Ecografo, Frecuencia, Onda, Piezoeléctrico, Reflexión, Refracción, Resolución, Transductor, Ultrasonido. 


\section{Introduction}

Ultrasound, U.S., means the sonic vibration whose frequency exceeds $20 \mathrm{kHz}$, is a mechanical wave motion, which are valid in the same physical laws that characterize mechanical waves [1].

The equipment designed for generating and controlling the intensity, frequency and power of these waves and their modulation forms have many applications both in the field of health as well in industrial applications.

They are very varied functions that are performed with ultrasonic equipment in medicine, since the deployment of the internal image of organs for noninvasive procedures to the application of massage and heat therapy in deep muscle tissue, especially sensitive musculoskeletal heat treatment [2] for which there have been made models that predict the mechanical and thermal effects in biological material [3], or for the study of different sports injuries [4] and in rheumatology [5] [6] [7]

This technology can also be used to measure blood flow [8] and blood pressure without invading organs of the body, as well as the changes in blood flow and inflammation associated with posttraumatic states [9]. Blood pressure and blood flow is measured by a technique which applies the Doppler Effect, [10] which consists in increasing frequency of a sound wave reflected by a body approaching the sound source, or decreasing upon removal. A person can easily observe this effect by emitting a steady tone and then quickly moving his hand to his mouth, and then he will hear the increase in frequency due to the motion of his hand. Applying ultrasound techniques using Doppler spectral simulation are used especially in the heart organs [11] [12] as well in the study of infertility [13], or in new color techniques [14] [15] [16]

The ultrasonic imaging or graphical reconstruction of internal organs is achieved by taking advantage of echoes that are produced with ultrasonic wave reflection applied to the tissues. Ultrasonic waves are partially reflected from the boundaries between different tissues, as do the ripples in the water when they find different objects in its path, the magnitude of the reflected wave depends on the density difference at the border of the obstacle point found by the incident wave. Therefore, it is possible to distinguish the boundary between different materials and with this principle construct images of border, making it possible to differentiate benign and malignant lesions in the diagnosis of cancer, e.g.: breast [17] [18], thyroid [19] [20] [21]or liver (laparoscopy) [22]; contrast ultrasound (CEUS) has recently become an important technology for lesion detection and characterization in cancer diagnosis [23]. The implication of this application in therapeutic and diagnostic procedures has been studied for the procedures in brain diagnosis [24] and Trans cranial [25] or osteoporosis [26] [27] More precisely location of important organs in the diagnosis of the common carotid artery can be performed automatically [28] [29] Also it displays different and auditory systems [30], upper gastrointestinal (esophagus) [31], and neurologic using high frequency U.S. [32] [33], the genitourinary [34] gastrointestinal endoscopy [35] or prostate exams Trans rectal [36] [37] [38] and the seminal duct [39].

U.S. applications are not limited only to medical diagnosis [40], but also extends to therapeutic applications [41] [42] [43], such as the U.S. low frequency (20 to $100 \mathrm{kHz}$ ) used in treatment of chronic rhino sinusitis [44] in sonoforesis (transdermal drug emission U.S.), dental [45] [46], ocular surgery [47], body contouring, kidney stone disruption and removal of blood clots) as well in ultrasonic drugs [48]; U.S. use in drug delivery has been spreading in the fields of cardiology and oncology for a variety of therapeutic agents such as small drug molecules, biological products and nucleic acid [49] [50]. Not to mention U.S. promising techniques or high-intensity focused (HIFU) to treat cancerous tumors allow full and non-invasive [51], psoriasis [52], dermatology [53], vascular procedures [54], among others.

There is also Physiotherapy utilization [55] as the treatment of cervical pain [56] [57], its use in surgical and medical instruments (20 to $60 \mathrm{kHz}$ ) for dissection, ablation [58] [59], fragmentation and removal of biological tissue [60], activation of transplanted organs [61], biopsies [62] [63], vacuum biopsies [64], orthodontics [65], in obstetrics [66] and ambulatory gynecology [67] [68], pediatric anesthesia [69], forensic examinations [70] or simply to disinfect medical instruments [71].

For therapeutic application of nebulization, employing the cavitation effect produced by ultrasonic shock waves with higher power breaking the molecules of the liquid in the nebulizer, creating a sort of vapor which can push some drugs, the steam is directed to be breathed by the patient undergoing these treatments. As the bubbles 


\section{TECCIENCIA}

generated by cavitation can affect scheduled treatment studies have been conducted to understand the dynamics of these [72] [73] [74] and its effect on the lesions [75] [76] as well as for the release kinetics of a drug by cavitation effects [77] [78].

Biological effects induced by the U.S. are generally classified into thermal and non-thermal mechanisms [79]. In heat therapy, using the fact that ultrasonic wave of a certain power can cause vibration material onto a tissue and heat it, it is the heat the variable that produce therapeutic effects [80]. The powers employed in this medical application are barely above $5 \mathrm{~W} / \mathrm{cm}^{2}$ to penetrate tissue [81].

Using this same principle can also be designed fetal monitors, using an FM demodulator, which allows sound to play in terms of the movements of the heart and the body of the baby [82] [83] [84] [85] [86], in the same way it can build an equipment to detect movement within the body to establish whether or not exist a pathological state [87], this is the foundation of electronic stethoscope [88]. However, ultrasound images have the problem of limiting the comparison of two sequences from two or more means [89], but compressing and stacking transforming congruently with multivariate analysis techniques this defect can be corrected allowing the detection, visualization, comparison and quantification of the dynamic between muscle skeleton movements, which has a high potential in pediatric patients [90] [91] [92] thus leading orthopedic clinic interesting applications: study of muscle injuries, post-surgical evaluations, rehabilitation and athletic training interventions [93] [94] [95]

\section{Basic definitions}

The ultrasonic sound vibrations corresponds to a frequency above $20 \mathrm{kHz}$ [96]. For propagation of the wave motion are valid the same physical laws to mechanical vibrations. This work deals with the necessary concepts to facilitate the understanding of medical applications of ultrasound, the reader deeply studying literature [97] [98] [99] [100]. In this context are presented different types of waves, thus:

Spherical waves and surface waves according to U.S. generating source is greater or smaller in diameter than the wavelength.
Longitudinal waves and transverse waves propagating according to the directions of oscillation no matter if are identical or are at right angles respectively. In biological substances only longitudinal waves are presented. Ultrasonic frequencies are used in medicine in the range of 1 to $15 \mathrm{MHz}$

\subsection{Characteristic values of the ultrasound waves}

The ultrasound wave equation depends on the distance between the center of excitation and the site to consider $\mathbf{a}$, also depends on the time $\mathbf{t}$, after excitation, as well as the amplitude $\mathbf{A}$ and $\omega$ the angular frequency of mechanical disturbance emitted by the vibration source.

$$
\begin{gathered}
A_{s}=A \sin (\omega t-k a) \\
\text { With } k=2 \pi / \lambda=2 \pi f /{ }_{c}=\omega / c \\
A_{s}=A \sin (\omega t-\omega a / c) \\
\text { ie: } \quad A_{s}=A \sin \omega(t-a / c)
\end{gathered}
$$

Where:

$A_{s}:$ Elongation or oscillating particle distance of its rest position.

$\omega:$ angular or radian frequency.

a: Distance between the center of excitement and the site consideration.

Particle velocity, $v$, in the mechanical motion is given by

$$
\left.v=\frac{d A_{s}}{d t}=A \omega \cos \omega(t-a / c)\right)
$$

With $v_{m}=A \omega$ as the maximum instantaneous velocity.

Due to the presence of the sound wave, the medium is subjected to a pressure $\mathrm{P}$

According to Newtonian equality movement have:

$$
\frac{d P}{d a}=\rho \frac{d^{2} A_{s}}{d t^{2}}=-\rho A \omega^{2} \sin \omega(t-a / c)
$$

Where $\rho$ is the density of the medium

Integrating over a to get:

$$
P=P_{0}+A \rho c \omega \cos \omega(t-a / c)
$$

Being $P_{0}$ is the pressure when there is no sound. 


\section{TECCIENCIA}

The amplitude of the pressure signal $\mathrm{P}$ or variation regarding Po will be:

$$
P_{m}=A \omega \rho c=v_{m} \rho c
$$

A variable of interest is the sonic intensity I, which is the ratio of the sonic power that reaches a surface, given per unit area $S$, remembering that the power is the energy per unit time, and the kinetic energy is given by:

$$
E=\frac{1}{2} m v^{2}
$$

Can be expressed sonic intensity I, such as:

$$
I=\frac{E / t}{S}=\frac{E}{t S}=\frac{1}{2} \frac{m v^{2}}{t S}=\frac{1}{2} \frac{m v^{2} l}{t V}=\frac{1}{2} \rho c v^{2}
$$

Because:

$$
S=V / l, \quad c=l / t, \quad \rho=m / V
$$

According to which $\mathrm{V}$ is the volume and 1 the distance traveled.

Equation (6) can be expressed in the following ways:

$$
I=\frac{1}{2} \rho c \omega^{2} A^{2}=\frac{1}{2} P_{m} v_{m}=\frac{1}{2} \frac{P_{m}^{2}}{\rho c}
$$

The intensity is expressed in $W / \mathrm{cm}^{2}$. Increasing the intensity of the ripple increases the magnitude of the mechanical vibrations and movements of the particles and therefore the magnitude of the received echoes when these are to be processed. The intensity used in medical diagnosis oscillate between 10 and $50 \mathrm{~mW} / \mathrm{cm}^{2}$, while in therapy, as in the case of diathermy can work in a range of 1 to $3 \mathrm{~W} / \mathrm{cm}^{2}$ There are other uses as cavitation in which the destruction of molecules are intended as in lithotripsy or in nebulization it works with intensities from 10 to $20 \mathrm{~W} / \mathrm{cm}^{2}$ [101]

Another magnitude to consider is the speed of ultrasound through a medium; this depends on the density and compressibility of the same, the denser it might be, higher speed of ultrasound will be. [102]

Knowing the speed of ultrasound in a medium, one can calculate the depth of reflection points correspond to generate echoes, if it can find the time that it takes to return each echo produced by a change in tissue [103]. Above is the principle on which teams are based diagnostic imaging reconstruction with ultrasound [104].
By means of the Doppler Effect, once known the speed of ultrasound incident on the blood as a stream into a vein or an artery, it can calculate the speed of the reflecting surface when calculated or measured changes in frequency [105] [106] [107]

In the human body the ultrasound velocity is between 1,500 and $1,660 \mathrm{~m} / \mathrm{s}$, being in the bones of $3.360 \mathrm{~m} / \mathrm{s}$ [108].

In Table No. 1, presented below, we can see how in different media U.S. speed varies in relation to the frequency and as a function of the density can be set to the acoustic impedance. [109]

The acoustic impedance, $\mathrm{Z}$, is the resistance of each tissue to ultrasound passage and is defined as:

$$
Z=\rho c
$$

acoustic shadowing due to the high impedance of the bone the beam is reflected almost completely, and behind this tissue, no new resonances are originate, owing to these differences in density occur sonic shadows behind gallbladder stones and air behind the gastrointestinal tract [110] [111].

\subsection{Ultrasound fields}

It is defined as the middle or field where ultrasound waves are propagate, it could be though that with the emission from a circular ultrasonic generator the field correspond to a cylinder in the direction of propagation, but this is true only in the area next to the ultrasound source because the divergence from the beam source is made divergent, opening like a cone with divergence angle $\gamma$, for the foregoing the cylindrical zone is defined as a near field and the zone beginning from the dispersion as a spread far field [112]. See Figure No. 1.

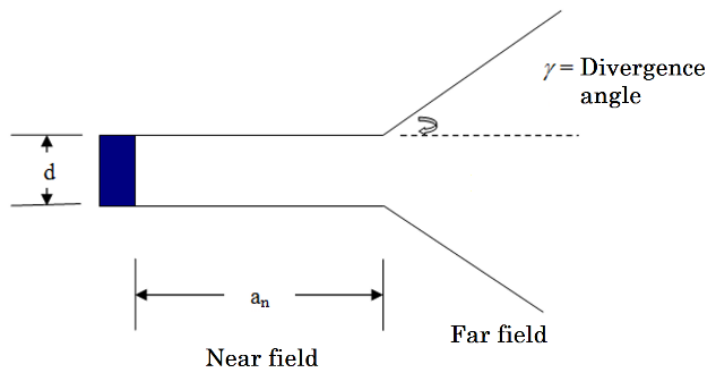

Figure 1. Ultrasound fields. 


\section{TECCIENCLA}

Table 1. Ultrasonic variables depending on the medium.

\begin{tabular}{|c|c|c|c|c|}
\hline Medium & $\begin{array}{c}\text { Speed } \boldsymbol{c} \\
m / s\end{array}$ & $\begin{array}{c}\text { Frecuency } \boldsymbol{f} \\
M H z\end{array}$ & $\begin{array}{c}\text { Density } \boldsymbol{\rho} \\
g / \mathrm{cm}^{3}\end{array}$ & $\begin{array}{c}\text { Acustic } \\
\text { Impedance } \boldsymbol{Z} \times \mathbf{1 0}^{-\mathbf{5}} \\
\mathrm{g} / \mathrm{cm}^{2} \boldsymbol{s}\end{array}$ \\
\hline Air & 330 & 2,5 & 0,0013 & 0,0004 \\
\hline Water & 1.495 & 1,5 & 0,997 & 1,49 \\
\hline Blood & 1.540 & 2,5 & 1,06 & 1,63 \\
\hline Muscle & 1.568 & 1,8 & 1,056 & 1,66 \\
\hline Liver & 1.570 & 1,8 & 1,055 & 1,66 \\
\hline Kidney & 1.560 & 1,8 & 1,038 & 1,62 \\
\hline Grease & 1.476 & 1,8 & 0,928 & 1,37 \\
\hline Brain & 1.521 & 2,0 & 1,041 & 1,58 \\
\hline Bone & 3.360 & 0,8 & 1,85 & 6,20 \\
\hline
\end{tabular}

Behind the bones it can be form what is called

When the size of the transducer that generates the ultrasound is small compared to the wavelength, $\lambda$, originates divergent propagation circular prism shaped, practically without giving rise to a nearby field, as shown in the previous figure.

For very large $d / \lambda,(d>\lambda)$, the ultrasound beam is emitted as somewhat cylindrical, ending in the near field, where it undergoes a divergence that characterizes the far field. The cylindrical portion is known as near-field, which has a length a_n, given by the expression:

$$
a_{n}=\frac{d^{2}-\lambda^{2}}{4 \lambda}
$$

For $\mathrm{d} \gg \lambda$

$$
a_{n}=\frac{d^{2}}{4 \lambda}=\frac{R^{2}}{\lambda}
$$

With $\mathrm{R}$ as the radius of the transducer.

After ending the near field, comes the farther field in which the U.S. is propagated divergently, the divergence angle $\gamma$ is given by the expression:

$$
\sin \gamma=\frac{k \lambda}{d}
$$

Where $\mathrm{k}$ depends on the fall in the amplitude of the sound pressure that a pressure drop to zero will have a value of $\mathrm{k}=1.22$, while $\mathrm{d}$ is the transducer diameter.

\section{Acoustic phenomena}

Now it is describe wave phenomena of reflection, refraction and absorption for the U.S., its mathematical modeling and physical characteristics that allow its technological application in the field of medicine.

\subsection{Reflection}

For ultrasound reflection apply the laws of reflection of optics:

Angle of incidence $=$ angle of reflection

The reflected part of the oscillation is given by the reflection factor $\mathrm{r}$ :

$$
r=\frac{\rho_{2} c_{2}-\rho_{1} c_{1}}{\rho_{2} c_{2}+\rho_{1} c_{1}}=\frac{z_{2}-z_{1}}{z_{2}+z_{1}} \gamma=\frac{k \lambda}{d}
$$

The reflection factor $\mathbf{r}$ is regarded as an absolute value, according to equation (12), each time you register a density difference in the path of the ultrasonic wave will produce an echo or reflection of the wave. When a small density difference between media or organic substances, reflection is very small, it will require a high sensitivity of the receiver in systems that exploit the reflections such as image reconstruction from echoes [113].

In the following table are experimental values of the reflection factor $\mathbf{r}$ and the percentage of reflected energy in different tissue interfaces: 


\section{TECCIENCIA}

Table 2. Factors of reflection and reflected energy percentages for different interfaces.

\begin{tabular}{|c|c|c|}
\hline Interface & $\begin{array}{c}\text { Reflection Factor } \\
\boldsymbol{r}\end{array}$ & $\begin{array}{c}\text { \% Reflected } \\
\text { Power } \\
\boldsymbol{\sigma}=\boldsymbol{r}^{\mathbf{2}} \times \mathbf{1 0 0} \%\end{array}$ \\
\hline Fat-Muscle & 0,100 & 1,00 \\
\hline Fat-Kidney & 0,080 & 0,64 \\
\hline Muscle-Blood & 0,030 & 0,09 \\
\hline Bone-Fat & 0,690 & 48,91 \\
\hline Bone-Muscle & 0,640 & 41,23 \\
\hline $\begin{array}{c}\text { Soft Tissue- } \\
\text { Water }\end{array}$ & 0,050 & 0,25 \\
\hline \begin{tabular}{c} 
Soft Tissue-Air \\
\hline
\end{tabular} & 0,995 & 99,99 \\
\hline
\end{tabular}

$$
Z=\frac{P_{m}}{v_{m}}=\frac{\rho v_{m} c}{v_{m}}=\rho c
$$

Pm: peak pressure, and VM: speed part. Peak

The acoustic impedance $\mathrm{Z}$ is the pressure developed by unit particle velocity, is a measure of the opposition to the propagation of ultrasound, the above equation was expressed in equation (8) and is analogous to Ohm's law electricity in which the pressure $\mathrm{P}$ is analogous to voltage $\mathrm{V}$ and the particle velocity $\mathrm{v}$ is analogous to the current $\mathrm{I}$.

The sound power peak $\operatorname{Pot}_{\mathrm{m}}$, is given by:

$$
\operatorname{Pot}_{m}=P_{m} v_{m}
$$

Under equation (8) can be expressed as:

$$
\operatorname{Pot}_{m}=v_{m}^{2} Z=\frac{P_{m}^{2}}{Z}
$$

Considering only effective values, we have:

$$
P o t=P v=v^{2} Z=\frac{P^{2}}{Z}
$$

To set the portion of reflected energy $\sigma$, it is assumed that this relationship is the same as the reflected power to the incident power, and that both the incident and reflected wave are given in the first half, which has $\boldsymbol{Z}_{\mathbf{1}}$, impedance with which gives:

$$
\sigma=\frac{\text { ot }_{2}}{\text { Pot }_{1}}=\frac{\frac{P_{2}^{2}}{Z_{1}}}{\frac{P_{1}^{2}}{Z_{1}}}=\frac{P_{2}^{2}}{P_{1}^{2}}=\left(\frac{P_{2}}{P_{1}}\right)^{2}
$$

As the pressure of the reflected wave:

$$
P_{2}=r P_{1}
$$

Where $r$ is the reflection factor, then the portion of reflected energy is:

$$
\sigma=\left(\frac{P_{2}}{P_{1}}\right)^{2}=\left(\frac{r P_{1}}{P_{1}}\right)^{2}=r^{2}
$$

That is, the ratio of reflected energy corresponds to the square of the reflection factor.

In the management of diagnostic imaging, an important factor in design is the repetition rate of the bursts fr, which must satisfy the condition:

$$
F_{r}<\frac{c}{2 D_{\text {máx }}}
$$

Where $\mathrm{c}$ is the speed of sound in the medium, and $\boldsymbol{D}_{\text {máx. }}$ is the maximum penetration to be observed, which logically should be in the near field, this condition avoids the ambiguity of time frame, this means that before send a new cross, it should receive the echoes of the last.

It is important to observe the last value of Table No 2 , which occurs in practice in the case of air from the lungs, or in the presence of intestinal gas. If the U.S. falls in an area where there is air or gas, it would reflect almost completely, causing in the region behind a sonic shadow. Precisely to avoid acoustic shadowing by the presence of air, it is necessary to be placed between the skin and the gel or paste a transducer coupling which prevents the thin layer of air between them, it reflects most of the ultrasonic wave affecting the possibility of observation proposal. In practice there is used an aqueous gelatin gel, or mineral oil

\subsection{Refraction}

For refraction is valid the relationship:

$$
I_{R}=\frac{\sin \alpha_{1}}{\sin \alpha_{2}}=\frac{c_{1}}{c_{2}}
$$

Where:

$I_{R}:$ Refractive index

$\alpha_{1}$ : Incidence angle

$\alpha_{1}$ : Refraction angle

$c_{1}$ : Speed of sound in the medium 11 , 


\section{TECCIENCLA}

$c_{2}$ : Speed of sound in the medium 2.

In the interfaces of change of tissue are refractions, according to equation (21). As the refractive index is constant (Snell's law) according to the angle of incidence, which is taken from the normal to the surface border, it will cause the angle of the beam refracted in respect to the same reference

In table No. 3 are shown some deviation values as a result of refraction at various interfaces, and i figure No. 2 shows the effect of refraction on a linear beam. The deviation corresponds to the difference between the incidence angle and the angle of refraction.

To illustrate it is taken as an example a change of means of fat $\left(\mathrm{c} \_1=1.476 \mathrm{~m} / \mathrm{s}\right)$ to muscle $(\mathrm{c} 2=$ $1.568 \mathrm{~m} / \mathrm{s}$ ) then the index of refraction of the fatmuscle interface is

$$
I_{R}=\frac{1,476 \mathrm{~m} / \mathrm{s}}{1,568 \mathrm{~m} / \mathrm{s}}=0,94133
$$

And an incidence angle of $30^{\circ},\left(\alpha_{1}=30^{\circ}\right)$ can find the angle of refraction, , $\alpha_{2}$ :

$$
\alpha_{2}=\sin ^{-1}\left(\frac{\sin \alpha_{1}}{I_{R}}\right)=\sin ^{-1}\left(\frac{\sin 30^{\circ}}{0,94133}\right)=32,08^{\circ}
$$

Then the deviation is $32.08^{\circ}$ :

Table 3. Some typical deviations.

\begin{tabular}{|c|c|}
\hline Interface & Desviation \\
\hline Bone- Soft Tissue & $19.3^{\circ}$ \\
\hline Muscle- Fat & $2.08^{\circ}$ \\
\hline Muscle- Liquid & $1.07^{\circ}$ \\
\hline
\end{tabular}

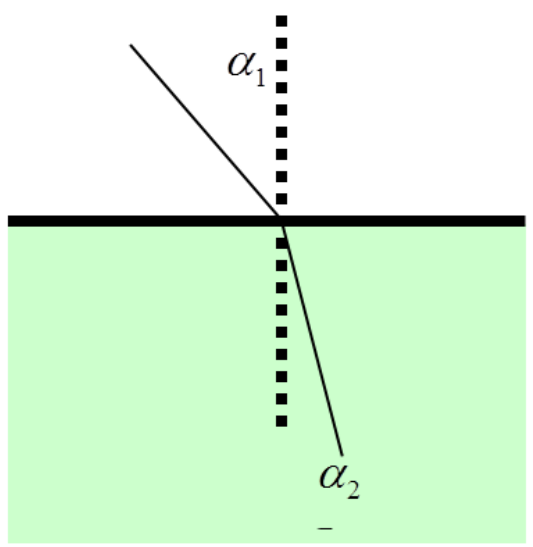

Figure 2. Refraction effect with the change of medium.

\subsection{Attenuation (Absorption)}

In a even wave with an initial intensity Io, which travels a distance $\mathrm{x}$, the intensity is given by the equation

$$
I=I_{0} e^{-2 \alpha x}
$$

With $\alpha$ as the coefficient of absorption, the attenuation must be $\mathrm{A}$, is defined by:

$$
A=\frac{I_{0}}{I}=e^{2 \alpha x}
$$

And expresses the weakening of the signal with the distance traveled, this attenuation expressed in decibels is:

$$
A(d B)=10 \log \frac{I_{0}}{I}=10 \log e^{2 \alpha x}
$$

Developing the above equation gives:

$$
\begin{aligned}
A(d B)=20 \alpha x \log e & =20 \cdot \alpha x \cdot 0,434 \\
& =8,68 \alpha x d B
\end{aligned}
$$

Making a graphic representation of the equation 22 is obtained Figure No. 3:

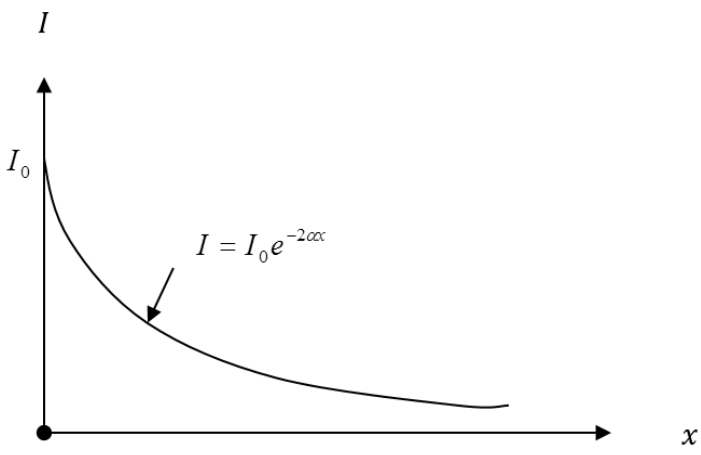

Figure 3. Sonic Intensity vs. Displacement.

In image reproduction equipment using ultrasonic echoes, there are systems that increase the termoir amplification of echoes of deep structures (depth compensation), in order to get an image to compensate for the attenuation that occurs in the course of ultrasonic beam and therefore more selective [114] [115]

Taking into the account that the absorption coefficient depends on the frequency and it is proportional it can be say that:

$$
A(d B) \approx f(M H z) \cdot x(c m)
$$

For soft tissue it has:

$$
A(d B)=0,9 x(\mathrm{~cm}) \cdot f(M H z)
$$




\section{TECCIENCIA}

From the last physical considerations it can be establishes that [113]:

- There is a correlation between the speed of sound and the density of the medium of propagation of ultrasonic disruption.

- In denser means propagation velocity is higher, but at the same time the attenuation is also greater.

- in processing of the ultrasonic signal, especially in equipment for reproducing images by reconstructing borders from the echoes, it is necessary to enter the socalled depth compensation to counteract the attenuation received by the deep echoes according to the Equation (22).

- The increasing of frequency of the ultrasonic signal, it also contributes to the attenuation, as discussed in equation (26).

\section{Power of resolution}

The resolving power of a pulsed ultrasound system is an important parameter in ultrasonography. There are two types of resolution, the resolution of depth or length and the cross or side.

The depth resolution refers to the ability of the system U.S. to distinguish successive obstaclespropagation direction, the resolution is determined by the length of the emitted pulses U.S. [116], as shown in the following figure:

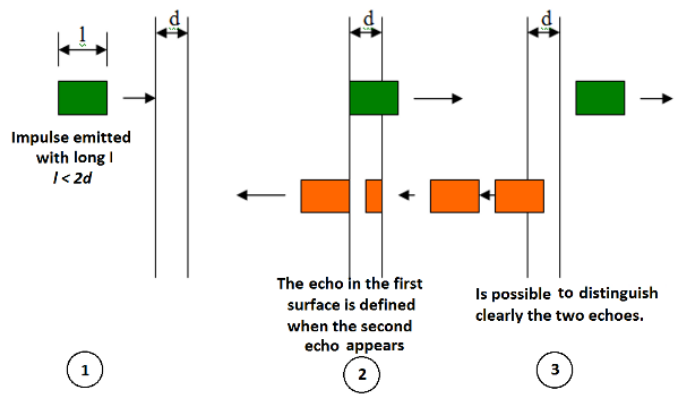

Figure 4. Appearance of echoes when 1> 2d.

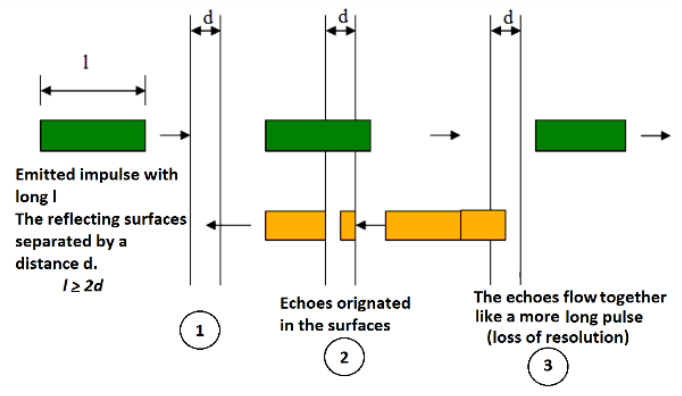

Figure 5. Appearance of echoes when $1<2 \mathrm{~d}$

To achieve good depth resolution, it is necessary to fill the condition $\boldsymbol{l}<2 \boldsymbol{d}$ thus, considering $\tau=l / c$ where pulse or burst.

$$
\tau<\frac{2 d}{c}
$$

So with a flurry of $2 \mathrm{MHz}$, in soft tissue $\left(c=1.54 \times 10^{6} \mathrm{~mm} / \mathrm{s}\right)$, for a pulse duration of $1 \mu s=10^{-6} \mathrm{~s}$, one can distinguish up to $1 \mathrm{~mm}$ distance between tissues. Studies were performed in the spatial variation of these acoustic parameters in human skin [117].

The transverse or lateral resolution is determined by the width of the transducer and the beam divergence angle in the far field [118]. This resolution is increased with increasing divergence.

It can be mention the following possibilities to improve the lateral resolution:

- -Decreased ultrasound transducer diameter.

- $\quad$-small pulse packets, this improves the two types of resolution.

- -Ring-shaped oscillators instead of the whole disk.

- $\quad$-Targeting additional geometric through lenses that increase the divergence

For example in sectorial reproduction systems is necessary to improve this type of resolution

\section{Conclusions}

Ultrasound applications according to their properties ranging from disease diagnosis of various organs through images, through fetal development to sports injuries, depending on whether they work in high or low range of frequencies. In recent years the use of U.S. as a diagnostic method has increased dramatically 
especially among cardiologists and radiologists [119].

For U.S. technological development in medicine there are studies of the interaction of U.S. with different tissues allowing their identification and their interfaces with other tissues from the assessment of the resistance offered by the passage of the U.S. average (impedance), the deviation by reflection (reflection factor) or refraction (refractive index) or absorption (attenuation).

Future trends in the U.S. clinical technology, in which among others are include 3D and 4D images, palpation distance using contrast agents for image enhancement, monitoring, application fusion between diagnostics and therapeutics and the ultrasonic drug delivery [120] [121] [122] [123], it is necessary to consider them to develop more research, in addition to the competition between imaging modalities and new uses of U.S. nonlinear is displayed not only in medicine but in other industries such as cosmetics and food [124] [125], biotechnology [126], veterinary applications [127] and nanotechnology [128] [129].

\section{References}

[1] T. Leighton, «What is ultrasound,» Process in Biophysics and Molecular Biology, vol. 93, $\mathrm{n}^{\circ}$ 1, pp. 383, 2007.

[2] O. M. Navarro y D. A. Parra, «Pediatric Musculoskeletal Ultrasound,» Ultrasound Clinics, vol. 4, no 4, pp. 457-470, 2009.

[3] F. Feng, A. Mal, M. Kabo, J. C. Wang y Y. Bar-Cohen, «The mechanical and thermal effects of focused ultrasound in a model biological material,» J Acoust Soc $A m$, vol. 117, no 4, pp. 2347-2355, 2005.

[4] Y. P. Chiang, T. Wang y S. F. Hiseh, «Application of Ultrasound in Sports Injury,» Journal of Medical Ultrasound, vol. 21, n 1, pp. 1-8, 2013.

[5] M. D'angostino y W. Schimidt, «Ultrasound guided inections in rheumatolohy,» Actual Knowledge on efficacy and procedures, vol. 27, $\mathrm{n}^{\circ} 2$, pp. 283-294, Best Practice \& research clinical rheumatology.

[6] F. Jhosua, «Ultrasound applications for the practicing theumatologist,» Best Practice \& Research clinical rheumatolohy, vol. 26, $\mathrm{n}^{\circ}$ 6, pp. 853-867, 2012.

[7] K. J. Li y S. Hsieh, «Clinical Application of Musculoskeletal Ultrasound in Rheumatic Diseases,» Journal of Medical Ultrasound, vol. 19, $\mathrm{n}^{\circ}$ 3, pp. 73-80, 2011.

[8] J. A. Jensen, «Medical ultrasound imaging,» Progress in Biophysics and Molecular Biology, vol. 93, $\mathrm{n}^{\circ}$ 1, pp. 153-165, 2007.

[9] R. S. Adler, «FUTURE AND NEW DEVELOPMENTS IN MUSCULOSKELETAL ULTRASOUND,»
Radiologic Clinics of North America, vol. 37, $\mathrm{n}^{\circ}$ 4, pp. 623-631, 1999.

[10] L. Aguilar, D. Steinman y R. S. Cobbold, «On the Synthesis of Sample Volumes for Real-Time Spectral Doppler Ultrasound Simulation,» Ultrasound in Medicine \& Biology, vol. 36, $\mathrm{n}^{\circ}$ 12, pp. 2107-2116, 2010.

[11] J. Evans, R. Skidmore, N. Luckman y P. Wells, «A new approach to the noninvasive measurement of cardiac output using an annular array doppler techniqueâ€’'I. Theoretical considerations and ultrasonic fields,» Ultrasound in Medicine \& Biology, vol. 15, $\mathrm{n}^{\circ}$ 3, pp. 167-178, 1989.

[12] M. Hung y W. J. Chemg, «Clinical Applications of Transthoracic Doppler Echocardiographic Coronary Flow Reserve Measurements in the Left Anterior Descending Coronary Artery,» Journal of Medical Ultrasound, vol. 19, n ${ }^{\circ}$ 4, pp. 115-121, 2011.

[13] C. K. Chen, H. M. Wu y Y. K. Soong, «Clinical Application of Ultrasound in Infertility: From Twodimensional to Three-dimensional,» Journal of Medical Ultrasound, vol. 15, n 2, pp. 126-133, 2007.

[14] W. H. Hsu, «Clinical Applications of Color Doppler Ultrasound in Chest Medicine,» Journal of Medical Ultrasound, vol. 15, n 3, pp. 141-151, 2007.

[15] T. L. Huang, «The Role of Color Doppler Ultrasound in Living Donor Liver Transplantation,» Journal of Medical Ultrasound, vol. 16, $\mathrm{n}^{\circ}$ 3, pp. 177-187, 2008.

[16] N. Ranjendran y B. Sundaresan, «Efficacy of Ultrasound and Color Power Doppler as a Monitoring Tool in the Healing of Endodontic Periapical Lesions,» Journal of Endodontics, vol. 33, $\mathrm{n}^{\circ}$ 2, pp. 181-186, 2007.

[17] S. M. Alhabshi, K. Rahmat, N. A. Halim, A. Aziz, S. Radhika, G. Gan, A. Vijayananthan, C. Westerhout, M. Mohd-shah, S. Jazle, N. Harlina y R. Muhammad, «Semi-Quantitative and Qualitative Assessment of Breast Ultrasound Elastography in differentiatin betwwen malignant and qualitative assessment of breast ultrasound elastrography in differentiatin between malignant and benign lesions,» Ultrasound in medicine \& Biolohy, vol. 39, $\mathrm{n}^{\circ} 4$, pp. 567-578, 2013.

[18] A. Jalian, S. B. Mashorhor, H. R. Mahmud, M. I. Saripan, R. B. Ramli y B. Karasfi, «Computer-aided detection/diagnosis of breast cancer in mammography and ultrasound: a review,» Clinical Imaging, vol. $37, \mathrm{n}^{\circ}$ 3, pp. 420-426, 2013.

[19] A. Basarab, H. Liebgott, F. Morestin, A. Lyshchik, T. higashi, R. Asato y P. Delachartre, «A method for vector displacement estimation with ultrasound imaging and its application for thyroid nodular disease,» Medical Image Analysis, vol. 12, n 3, pp. 259-274, 2008.

[20] T. G. Kangelaris, T. B. Kim y . L. A. Orloff, «Role of Ultrasound in Thyroid Disorders,» Ultrasound Clinics, vol. 7, n 2, pp. 197-210, 2012.

[21] G. T. Kangelaris, T. Kim y L. A. Orloff, «Role of Ultrasound in Thyroid Disorders,» Otolaryngologic Clinics of North America, vol. 43, $\mathrm{n}^{\circ}$ 6, pp. 1209-1227, 2010.

[22] J. C. Catheline, R. Turner y G. Champault, «Laparoscopic ultrasound of the liver,» European Journal of Ultrasound, vol. 12, n 2, pp. 169-177, 2000.

[23] P. Angelelli, K. Nylund, O. Gilja y H. Hauser, «Interactive visual analysis of contrast-enhanced 


\section{TECCIENCIA}

ultrasound data based on small neighborhood statistics,» Computers \& Graphics, vol. 35, n² 2, pp. 218-226, 2011.

[24] J. Aarnio, G. T. Clement y K. Hynynen, «A new ultrasound method for determining the acoustic phase shifts caused by the skull bone,», Ultrasound in Medicine \& Biology, vol. 31, $\mathrm{n}^{\circ}$ 6, pp. 771-780, 2005.

[25] S. Behrens, K. Spengos, M. Daffertshofer, H. Schroeck, C. E. Demfle y M. Hennerici, «Transcranial ultrasoundimproved thrombolysis: diagnostic vs. therapeutic ultrasound,» Ultrasound in Medicine \& Biology, vol. 27, no 2, pp. 1683-1689, 2001.

[26] G. Guglielmi, G. Scalzo, F. de Terlizzi y W. C. Pe, "Quantitative Ultrasound in Osteoporosis and Bone Metabolism Pathologies,» Radiologic Clinics of North America, vol. 48, nº 3, pp. 577-588, 2010.

[27] M. A. Krieg, R. Barkmann, S. Gonnelli, A. Stewart, D. C. Bauer, L. Del Rio Barquero, J. J. Kaufman, R. Lorenc, P. D. Miller, W. P. Olszynki, C. Poiana, A. M. Schott, . M. Lewiecki y D. Hans , «Quantitative Ultrasound in the Management of Osteoporosis: The 2007 ISCD Official positions,» Journal of clinical Densitometry, vol. 11, $\mathrm{n}^{\circ}$ 1, pp. 163-187, 2008

[28] B. Bennes, J. Karasek, R. Burget y K. Riha, «Automatically designed machine vision system for the localization of CCA transverse section in ultrasound images,» Computer Methods and Programs in Biomedicine, vol. 109, $\mathrm{n}^{\circ}$ 1, pp. 92-103, 2013.

[29] K.-C. C.-C. H.-J. C. D.-R. C. E. T. y. W. K. M. «. R.-F. Chang, «Whole breast computer-aided screening using free-hand ultrasound,» de International congress series, 2009

[30] J. A. Brown, Z. Torbatian, R. B. Adamson, R. Van Wijhe, R. J. Pennings, G. Lockwood y M. L. Bance, «High- frecuency ex vivo ultrasound imaging of the auditory system,» Ultrasound in medicine \&biology, vol. 35, n 11, pp. 1899-1907, 2009.

[31] S. Inglis, D. Christie y N. Plevirs, «A Novel ThreeDimensional Endoscopic Ultrasound Technique for the Freehand Examination of the Oesophagus,» Ultrasound in Medicine \& Biology, vol. 37, $\mathrm{n}^{\circ} 11$, pp. 1779-1790, 2011.

[32] J. Foley, S. Vaezy y L. A. Crum, «Applications of highintensity focused ultrasound in medicine: Spotlight on neurological applications,» Applied Acoustics, vol. 68, $\mathrm{n}^{\circ} 3$, pp. 245-259, 2007.

[33] L. T. E. D. I. I. Gavrilov, «Application of focused ultrasound for the stimulation of neural structures,» Ultrasound in Medicine \& Biology, vol. 22, $\mathrm{n}^{\circ}$ 2, pp. 179-192, 1966.

[34] J. D. D. V. S. Christensen, «New Advances in Genitourinary Ultrasound,» Ultrasound Clinics, vol. 2, no 1, pp. 105-114, 2007.

[35] R. P. D. Kundu, «Clinical Application of Intraductal Ultrasound During Endoscopic Retrograde Cholangiopancreatography,» Gastrointestinal Endoscopy Clinics of North America, vol. 19, $\mathrm{n}^{\circ}$ 4, pp. 615-628, 2009

[36] M. P. B. E. H. Bustince, J. Fernandez, P. Melo-Pinto, P. Couto, H. Tizhoosh y J. Montero, «Ignorance functions. An application to the calculation of the threshold in prostate ultrasound images,» Fuzzy Sets and Systems, vol. $161, n^{\circ} 1$, pp. $20-36,2010$

[37] A. Fenster, K. Surry, W. Smith y D. B. Downey, «The use of three-dimensional ultrasound imaging in breast biopsy and prostate therapy,» Measurement, vol. $36, \mathrm{n}^{\circ}$ 3, pp. 245-256, 2004.

[38] D. R. Holmes, B. J. Davis, C. J. Bruce y R. A. Robb, «3D visualization, analysis, and treatment of the prostate using trans-urethral ultrasound,» Computerized Medical Imaging and Graphics, vol. 27, $\mathrm{n}^{\circ}$ 5, pp. 339394, 2003.

[39] S.-H. Kim, M.-H. Moon y B.-K. Park, «Clinical Applications of Transrectal Ultrasound in the Prostate and Seminal Tract,» Journal of Medical Ultrasound, vol. 10, nº 4, pp. 181-190, 2002.

[40] G. Schmitz, «Ultrasound in Medical Diagnosis,,» de Chapter 1.3.4 - , London , Academic Press,, 2002, pp. 162-174.

[41] L. Crum, M. Bailey, J. H. Hwang, V. Khokhlova y O. Sapozhnikov, «Therapeutic ultrasound: Recent trends and future perspectives,» Physics Procedia, vol. $3, \mathrm{n}^{\circ} 1$, pp. 25-34, 2010.

[42] G. ter Haar, «Therapeutic applications of ultrasound,» Progress in Biophysics and Molecular Biology, vol. 93, $\mathrm{n}^{\circ}$ 1, pp. 111-129, 2007.

[43] A. Siegenthaler, «Ultrasound guided interventional pain treatment,» Trends in Anaesthesia and Critical Care, vol. 2, no 3, pp. 133-137, 2012

[44] J. Bartley y D. Young, «Ultrasound as a treatment for chronic rhinosinusitis,» Medical Hypotheses, vol. 73, $\mathrm{n}^{\circ}$ 1, pp. 15-17, 2009.

[45] B. Scheven, R. Shelton, P. Cooper, A. Walmsley y A. Smith, «Therapeutic ultrasound for dental tissue repair,» Medical Hypotheses, vol. 73, nº 4, pp. 591-593, 2009.

[46] A. Walmsley, «Applications of ultrasound in dentistry,» Ultrasound in Medicine \& Biology, vol. 14, $\mathrm{n}^{\circ}$ 1, pp. 7 14, 1988.

[47] M. Nabili, H. Patel, S. P. Mahesh, J. Liu, C. Geist y V. Zderic, «Ultrasound-Enhanced Delivery of Antibiotics and Anti-Inflammatory Drugs Into the Eye,» Ultrasound in Medicine \& Biology, vol. 39, $\mathrm{n}^{\circ}$ 4, pp. 638-646, 2013.

[48] F. Ahmadi, I. V. McLoughlin, S. Chauhan y G. ter Haar, «Bio-effects and safety of low-intensity, low-frequency ultrasonic exposure,» Progress in Biophysics and Molecular Biology, vol. 108, nº 3, pp. 119-138, 2012.

[49] M. Böhmer, A. Klibanov, K. Tiemann, C. Hall, H. Gruell y O. Steinbach, «Ultrasound triggered imageguided drug delivery,» European Journal Of Radiology, vol. 70, no 2, pp. 242-253, 2009.

[50] H. Epstein-Barash, G. Orbey, B. E. Polat, R. H. Ewoldt, J. Feshitan, R. Langer, M. A. Borden y D. S. Kohane, «A microcomposite hydrogel for repeated on-demand ultrasound-triggered drug delivery,» Biomaterials, vol. 31, no 19, pp. 5208-5217, 2010.

[51] O. Al-Bataineh, J. Jenne y P. Huber, «Clinical and future applications of high intensity focused ultrasound in cancer,» Cancer Treatment Reviews, vol. 38, $\mathrm{n}^{\circ} 5$, pp. 346-353, 2012.

[52] A. R. Clark, S. R. Feldman y J. L. Jorizzo, «Ultrasonic therapy for psoriasis,» Journal of the European Academy of Dermatology and Venereology, vol. $4, \mathrm{n}^{\circ} 1$, pp. 58-61, 1995.

[53] R. Kleinerman, T. B. Whang, R. L. Bard y E. S. Marmur, «Ultrasound in dermatology: Principles and applications,» Journal of the American Academy of Dermatology, vol. 67, nº 3, pp. 478-487, 2012. 
[54] S. W. Khoo y D. C. Han, «The Use of Ultrasound in Vascular Procedures,» Surgical Clinics of North America, vol. 91, nº 1, pp. 173-184, 2011.

[55] S. McKiernan, P. Chiarelli y H. Warren-Forward, «Diagnostic ultrasound use in physiotherapy, emergency medicine, and anaesthesiology,» Radiography, vol. 16, n 2, pp. 154-159, 2010.

[56] C. Alcázar y R. M. Rodriguez, «Aplicación de ultrasonidos en el dolor cervical de origen inespecífico,» Fisioterapia, vol. 29, nº 4, 2007.

[57] L. Ghamkhar, M. Emami, M. A. Mohseni-Bandpei y H. Behtash, «Application of rehabilitative ultrasound in the assessment of low back pain: A literature review,» Journal of Bodywork and Movement Therapies, vol. 15, no 4, pp. 465-477, 2011.

[58] S. Bharat, T. G. Fisher, T. Varghese, T. J. Hall, J. Jiang, E. L. Madsen, J. A. Zagzebski y F. T. Lee, «ThreeDimensional Electrode Displacement Elastography Using the Siemens C7F2 fourSight Four-Dimensional Ultrasound Transducer,» Ultrasound in medicine \& Biology, vol. 34, nº 8, pp. 1307-1316, 2008.

[59] A. Couppis, C. Damianou, P. Kyriacou, C. Lafon, C. J.Y. Chavrier y A. Birer, «Heart ablation using a planar rectangular high intensity ultrasound transducer and MRI guidance,» Ultrasonics, vol. 52, $\mathrm{n}^{\circ} 7$, pp. 821-829, 2012.

[60] B. O'Daly, E. Morris, G. Gavin, J. O'Byrne y G. McGuinness, «High-power Low-frequency Ultrasound: a Review of Tissue Dissection and Ablation in Medicine and Surgery,» Journal of Materials Processing Technology, vol. 200, $\mathrm{n}^{\circ}$ 1, pp. 35-58, 2008.

[61] S. Wang, Y. Li, Y. Ji, C.-M. Lin, C. Man y X.-X. Zheng, «Stem-cell-activated organ following ultrasound exposure: Better transplant option for organ transplantation,» Medical Hypotheses, vol. 74, $\mathrm{n}^{\circ}$ 1, pp. 147-149, 2010.

[62] A. B. Craig, W. R. Sherman y J. D. Will, «Medical Applications de Developing Virtual Reality Applications,» de Chapter 5, Boston, Morgan Kaufmann, 2009, pp. 145-187.

[63] A. Fenster, K. Surry, W. Smith, J. Gill y D. B. Downey, «3D ultrasound imaging: applications in image-guided therapy and biopsy.,» Computers \& Graphics, vol. 26, $\mathrm{n}^{\mathrm{o}}$ 4, pp. 557-568, 2002.

[64] C. Y. Lui y H. S. Lam, «Review of Ultrasound-guided Vacuum-assisted Breast Biopsy: Techniques and Applications,» Journal of Medical Ultrasound, vol. 10, $\mathrm{n}^{\mathrm{o}}$ 1, pp. 1-10, 2010.

[65] T. El-Bialy, I. El-Shamy y T. M. Graber, «Repair of orthodontically induced root resorption by ultrasound in humans.,» American Journal of Orthodontics and Dentofacial Orthopedics, vol. 126, no 2, pp. 186-193, 2009.

[66] S. H. Eik-Nes, «Chapter 1 Physics and instrumentation,» de Ultrasound in Obstetrics and Gynaecology, Edinburgh, Elsevier, 2009, pp. 1-20.

[67] N. N. Amso y A. Griffiths, «The role and applications of ultrasound in ambulatory gynaecology,» Best Practice \& Research Clinical Obstetrics \& Gynaecology, vol. 19, n 5, pp. 693-711, 2005.

[68] L. Coyne y N. J. Raine-Fenning, «Ultrasound in gynaecology and early pregnancy,» Obstetrics, Gynaecology \& Reproductive Medicine, vol. 20, $\mathrm{n}^{\circ}$ 6, pp. $181-189,2010$
[69] J. G. McCormack y S. Malherbe, «Applications of ultrasound in paediatric anaesthesia,» Current Anaesthesia \& Critical Care, vol. 19, ${ }^{\circ}$ 5, pp. 302-308, 2008.

[70] S. Uchigasaki, L. Oesterhelweg, A. Gehl, J. Sperhake, S. Oshida y N. Nemoto, «Application of compact ultrasound imaging device to postmortem diagnosis,» Forensic Science International, vol. $140, \mathrm{n}^{\circ} 1$, pp. 3341, 2004.

[71] L. Jatzawauk, H. Schöne y H. Pietsch, «How to improve instrument disinfection by ultrasound.,» Journal of Hospital Infection, vol. 1, pp. 80-83, 2001.

[72] W. Kreider, L. A. Crum, M. R. Bailey y O. A Sapozhnikov, «A reduced-order, single-bubble cavitation model with applications to therapeutic ultrasound,» Journal Acoust Soc Am, vol. 130, n 5, pp. 3511-3530, 2011.

[73] E.-A. Brujan, «Cardiovascular cavitation,» Medical Engineering \& Physics, vol. 31, $\mathrm{n}^{\circ}$ 7, pp. 742-751, 2009.

[74] W.-S. Chen, T. J. Matula y L. A. Crum, « The disappearance of ultrasound contrast bubbles: observations of bubble dissolution and cavitation nucleation,» Ultrasound in Medicine \& Biology, vol. 28, $\mathrm{n}^{\circ}$ 6, pp. 793-803, 2008.

[75] M. R. Bailey, L. N. Couret, O. A. Sapozhnikov, V. A. Khokhlova, G. ter Haar, S. Vaezy, X. Shi, R. Martin y L. A. Crum, «Use of overpressure to assess the role of bubbles in focused ultrasound lesion shape in vitro,» Ultrasound in Medicine \& Biology, vol. 27, $\mathrm{n}^{\circ}$ 5, pp. 695-708, 2001

[76] E. Brujan, «The role of cavitation microjets in the therapeutic applications of ultrasound,» Ultrasound in Medicine \& Biology, vol. 130, $\mathrm{n}^{\circ}$ 3, pp. 381-387, 2004.

[77] M. Afadzi, C. d. L. Davies, Y. H. Hansen, T. Johansen, A. K. Standal, R. Hansen, S.-E. Masoy, E. A. Nilssen y B. Angelsen, «Effect of Ultrasound Parameters on the Release of Liposomal Calcein,» Ultrasound in Medicine \& Biology, vol. 38, $\mathrm{n}^{\circ} 3$, pp. 476-486, 2012.

[78] S. Hernot y A. L. Klibanov, «Microbubbles in ultrasound-triggered drug and gene delivery,» Advanced Drug Delivery Reviews, vol. 60, nº 10, pp. 53-66, 2008.

[79] W. O'Briend, «Ultrasound- biophysics mechanisms,» Progress in Biophysics and Molecular Biology, vol. 93, $\mathrm{n}^{\circ}$ 1, pp. 212-255, 2007.

[80] G. Bouchoux, C. Lafon, R. Berriet, J. Y. Chapelon, G. Fleury y D. Cathignol, «Dual-Mode Ultrasound Transducer for Image-Guided Interstitial Thermal Therapy,» Ultrasound in Medicine \& Biology, vol. 34, $\mathrm{n}^{\circ}$ 4, pp. 607-616, 2008.

[81] M. Gertner, B. Wilson y M. Sherar, «Ultrasound properties of liver tissue during heating,» Ultrasound in Medicine \& Biology, vol. 23, nº 9, pp. 1395-1403, 1997.

[82] C.-H. Chang, C.-H. Yu, H.-C. Ko, F.-M. Chang y H.-Y. Chen, «Assessment of normal fetal liver blood flow using quantitative three-dimensional power Doppler ultrasound,» Ultrasound in Medicine \& Biology, vol. 29, $\mathrm{n}^{\circ}$ 7, pp. 943-949, 2003.

[83] C.-H. Chang, C.-H. Yu, F.-M. Chang, H.-C. Ko y H.-Y. Chen, «Volumetric assessment of normal fetal lungs using three-dimensional ultrasound,» Ultrasound in Medicine \& Biology, vol. 29, nº 7, pp. 935-942, 2003.

[84] F.-M. Chang, C.-H. Chang y H.-C. Ko, «Threedimensional Ultrasound in Prenatal Diagnosis and 
Reproductive Medicine,» Journal of Medical Ultrasound, vol. 20, $\mathrm{n}^{\circ} 3$, pp. 133-135, 2012.

[85] L.-W. Chang, F.-M. Chang, C.-H. Chang, C.-H. Yu, Y.C. Cheng y H.-Y. Chen, «Prenatal diagnosis of fetal multicystic dysplastic kidney with two-dimensional and three-dimensional ultrasound,» Ultrasound in Medicine \& Biology, vol. 28, $\mathrm{n}^{\circ}$ 7, pp. 853-858, 2002.

[86] C.-H. Chang, C.-H. Yu, H.-C. Ko, C.-L. Chen y F.-M. Chang, « Three-dimensional power Doppler ultrasound for the assessment of the fetal brain blood flow in normal gestation,» Ultrasound in Medicine \& Biology, vol. 29, nº 9, pp. 1273-1279, 2009.

[87] A. T. Dulay y J. A. Copel, « First-Trimester Ultrasound: Current Uses and Applications,» Seminars in Ultrasound, vol. 29, nº 2, pp. 121-131, 2008.

[88] I.-W. Lee, C.-H. Chang, Y.-C. Cheng, H.-C. Ko y F.-M. Chang, «A Review of Three-dimensional Ultrasound Applications in Fetal Growth Restriction,» Journal of Medical Ultrasound, vol. 20, $\mathrm{n}^{\circ}$ 3, pp. 142-149, 2012.

[89] J. A. Jensen, S. I. Nikolov, K. L. Gammelmark y M. H. Pedersen, «Synthetic aperture ultrasound imaging,» Ultrasonics, vol. 1, $\mathrm{n}^{\circ}$ 0, pp. 5-15, 2006.

[90] R. Bellah, «Ultrasound in pediatric musculoskeletal disease: Techniques and Applications,» Radiologic Clinics of North America., vol. 39, $\mathrm{n}^{\circ} 4$, pp. 597-618, 2001.

[91] K. P. Cross, «Bedside Ultrasound for Pediatric Long Bone Fractures,» Clinical Pediatric Emergency Medicine, vol. 12, $\mathrm{n}^{\mathrm{o}}$ 1, pp. 27-36, 2011.

[92] D. Dumitriu, M.-A. Galloy y M. Claudon, «New Techniques in Pediatric Ultrasound,» Ultrasound Clinics, vol. 5, $\mathrm{n}^{\circ}$ 1, pp. 153-169, 2010.

[93] T. Löfstedt, O. Ahnlund, M. Peolsson y J. Trygg, «Dynamic ultrasound imaging a multivariate approach for the analysis and comparison of time-dependent musculoskeletal movements,» BMC Med Imaging, vol. 12, no 1 , pp. 29-39, 2012.

[94] M. Peolsson, T. Lófstedt, S. Vogt, H. Stenlund, A. Arndt y J. Trygg, «Modelling human musculoskeletal functional movements using ultrasound imaging.,» BMC Med Imaging, vol. 10, $\mathrm{n}^{\circ}$ 1, pp. 9-11, 2010.

[95] J. L. Collinger, D. Gagnon, J. Jacobson, B. G. Impink y M. L. Boninger, «Reliability of Quantitative Ultrasound Measures of the Biceps and Supraspinatus Tendons,» Academic Radiology, vol. 16, $\mathrm{n}^{\circ} 11$, pp. 1424-1432, 2009.

[96] d. Castro y F. P. Capote, «Chapter 1 Introduction: Fundamentals of ultrasound and basis of its analytical uses,» Analytical Applications of Ultrasound, vol. 26, $\mathrm{n}^{\circ}$ 1, pp. 1-34, 2007.

[97] K. W. Beach, «Chapter 6 - Principles of Ultrasound Physics and Instrumentation: An Overview,»,» de Vascular Diagnosis, Philadelphia, Saunders, 2005, pp. 47-71.

[98] T. E. Herbener, «Ultrasounds physics: principles of ultrasonography,» Gastrointestinal Endoscopy, vol. 43, $\mathrm{n}^{\circ} 2$, pp. 54-55, 1996.

[99] C. X. Deng y F. L. Lizzi, «A review of physical phenomena associated with ultrasonic contrast agents and illustrative clinical applications,» Ultrasound in Medicine \& Biology, vol. 28, $\mathrm{n}^{\circ}$ 3, pp. 277-276, 2002.

[100] A. P. Sarvazyan, O. V. Rudenko y W. L. Nyborg, «Biomedical Applications of Radiation Force of Ultrasound: Historical Roots and Physical Basis,,»
Ultrasound in Medicine \& Biology, vol. 36, n 9, pp. 79 94, 2010.

[101] R. Clarke, «Modification of intensity distributions from large aperture ultrasound sources,» Ultrasound in Medicine \& Biology, vol. 21, nº 3, pp. 353-363, 1995.

[102] G. E. Sleefe y P. P. Lele, «On estimating the number density of random scatterers from backscattered acoustic signals,» ltrasound in Medicine \& Biology, vol. 14, n ${ }^{\circ} 8$, pp. 709-727, 1988.

[103] H. Zhao, P. Song, M. W. Urban, J. F. Greenleaf y S. Chen, «Shear Wave Speed Measurement Using an Unfocused Ultrasound Â Beam,» Ultrasound in Medicine \& Biology, vol. 38, $\mathrm{n}^{\circ}$ 9, pp. 46-55, 2012.

[104] M. A. Ellis, F. Viola y W. F. Walker, «Super-Resolution Image Reconstruction Using Diffuse Source Models,» Ultrasound in Medicine \& Biology, vol. 36, $\mathrm{n}^{\circ}$ 6, pp. 967-977, 2010.

[105] I. Güler y E. Derya, «Analysis of Doppler ultrasound signals based on fuzzy similarity index,» Expert Systems with Applications, vol. 31, $\mathrm{n}^{\circ}$ 1, pp. 130-136, 2006.

[106] I. Güler y E. Derya, «Feature saliency using signal-tonoise ratios in automated diagnostic systems developed for Doppler ultrasound signals,» Engineering Applications of artificial inteligence, vol. 19, $\mathrm{n}^{\circ} 1$, pp. 53-63, 2006.

[107] I. Guler y E. Derya , «Implementing wavelet/probabilistic neural networks for Doppler ultrasound blood flow signals,» Expert systems with aplications, vol. 33, $\mathrm{n}^{\mathrm{o}}$ 1, pp. 162-170, 2007.

[108] H.-C. Shin, R. Prager, H. Gomersall, N. Kingsbury y G. G. A. Treece, « Estimation of speed of sound in duallayered media using medical ultrasound image deconvolution,» Ultrasonics, vol. 50, ${ }^{\circ} 7$, pp. 16-25, 2010.

[109] X. Zhang, B. Qiang, R. Hubmayr, M. Urban, R. Kinnick y J. Greenleaf, « Noninvasive ultrasound image guided surface wave method for measuring the wave speed and estimating the elasticity of lungs: A feasibility study,» Ultrasonics, vol. 51, $\mathrm{n}^{\circ} 3$, pp. 289-295, 2011.

[110] S. Callé, J.-P. Remenieras, O. Bou Matar, M. Defontaine y F. Patat, "Application of nonlinear phenomena induced by focused ultrasound to bone imaging,» Ultrasound in Medicine \& Biology, vol. 29, no 3, pp. 465-472, 2003.

[111] J. Chen, L. Cheng, Z. Su y L. Qin, « Modeling elastic waves in coupled media: Estimate of soft tissue influence and application to quantitative ultrasound,» Ultrasonics, vol. 53, $\mathrm{n}^{\circ}$ 2, pp. 350-362, 2013.

[112] N. Nicholson y W. McDicken, « Mode propagation of ultrasound in hollow waveguides,» Ultrasonics, vol. 29, n 5, pp. 411-416, 1991.

[113] A. Sarvazyan, «Diversity of biomedical applications of acoustic radiation force,» Ultrasonics, vol. 50, $\mathrm{n}^{\circ} 2$, pp. 230-234, 2010

[114] M. Cloostermans, W. Verhoef y J. Thijssen, «Generalized description and tracking estimation of the frequency dependent attenuation of ultrasound in biological tissues,» Ultrasonic Imaging, vol. 7, $\mathrm{n}^{\circ}$ 2, pp. 133-141, 1985

[115] Y. Kanayama, N. Kamiyama, K. Maruyama y Y. Sumino, «Real-Time Ultrasound Attenuation Imaging of Diffuse Fatty LiverÂ Disease,» Ultrasound in Medicine \& Biology, vol. 39, $\mathrm{n}^{\circ}$ 4, pp. 692-705, 2013. 


\section{TECCIENCIA}

[116] J. Roelandt, «Ultrasound stethoscopy,» European Journal of Internal Medicine, vol. 15, $\mathrm{n}^{\circ}$ 6, pp. 337-347, 2004

[117] M. Lebertre, F. Ossant, L. Vaillant, S. Diridollou y F. Patat, «Spatial variation of acoustic parameters in human skin: an in vitro study between 22 and $45 \mathrm{MHz}$,» Ultrasound in Medicine \& Biology, vol. 28, $\mathrm{n}^{\circ}$ 5, pp. 599-615, 2002.

[118] S. Mehta y P. Antich, «Measurement of shear-wave velocity by ultrasound critical-angle reflectometry (UCR),» Ultrasound in Medicine \& Biology, vol. 23, $\mathrm{n}^{\circ}$ 7, pp. 23-26, 1997.

[119] D. C. Levin, V. M. Rao, A. J. Maitino, L. Parker y J. H Sunshine, «Comparative increases in utilization rates of ultrasound examinations among radiologists, cardiologists, and other physicians from 1993 to 2001,» Journal of the american college of radiology, vol. $1, \mathrm{n}^{\circ}$ 8, pp. 49-52, 2004.

[120] D. Park, H. Ryu, H. S. Kim, K.-S. Choi, H. Park y J. Seo, «Sonophoresis Using Ultrasound Contrast Agents for Transdermal Drug Delivery: An InÂ Vivo Experimental Study,» Ultrasound in Medicine \& Biology, vol. 38, no 4, pp. 42-50, 2012.

[121] N. Reznik, R. Williams y P. N. Burns, «Investigation of Vaporized Submicron Perfluorocarbon Droplets as an Ultrasound Contrast Agent,» Ultrasound in Medicine \& Biology, vol. 37, $\mathrm{n}^{\circ}$ 8, pp. 71-79, 2011.

[129] V. Singh, «Ultrasound hyperthermia control system for deep-seated tumours: Ex vivo study of excised tumours, modeling of thermal profile and future nanoengineering aspects,»IRBM, vol. 29, n 5 , pp. 326-336, 2008.
[122] R. Saini, J. M. Warram, A. G. Sorace, H. Umphrey, K. R. Zinn y K. Hoyt, «Model System Using Controlled Receptor Expression for an Evaluating Targeted Ultrasound Contrast Agents,» Ultrasound in Medicine \& Biology, vol. 37, nº 8, pp. 06-13, 2011.

[123] T. L. Szabo, «Diagnostic Ultrasound Imaging,» de 15 Ultrasound-induced bioeffects, Burlington, Academic Press, 2004, pp. 489-516.

[124] P. A. Lewin, "Nonlinear acoustics in ultrasound metrology and other selected applications,» Physics Procedia, vol. 3, n 1 , pp. 17-23, 2010.

[125] K. Vilkhu, R. Mawson, L. Simons y D. Bates, «Applications and opportunities for ultrasound assisted extraction in the food industry A review,» Innovative Food Science \& Emerging Technologies, vol. 9, no 2, pp. 161-169, 2008.

[126] E. V. Rokhina, P. Lens y J. Virkutyte, «Low-frequency ultrasound in biotechnology: state of the art,» Trends in Biotechnology, vol. 27, n 5, pp. 298-306, 2009.

[127] S. Ohlerth y R. T. O'Brien, «Contrast ultrasound: General principles and veterinary clinical applications,» The Veterinary Journal, vol. 174, $\mathrm{n}^{\circ} 3$, pp. 501-512, 2007.

[128] A. Shrestha, S. W. Fong, B. Khoo y A. Kishen, «Delivery of Antibacterial Nanoparticles into Dentinal Tubules Using High-intensity Focused Ultrasound,» Journal of endodontics, vol. 35, nº 7, pp. 28-33, 2009. 